\title{
Demographic and exploitation parameters of the blue shark, Prionace glauca in the Gulf of Guinea (Togo-Benin-Nigeria).
}

Houangninan Emmanuel Calèbe Midinoudéwa ${ }^{1,2,4}{ }^{*}$; Zacharie Sohou ${ }^{1,2}$; Samuel Kofi Tulashie, and Emile Didier Fiogbé $e^{1}$

${ }^{1}$ LRHZ/DZ/FaST/UAC : Laboratoire de Recherches sur les Zones Humides/Département de Zoologie/ Faculté des Sciences et Techniques/ Université d'Abomey-Calavi.

${ }^{2}$ IRHOB : Institut de Recherches Halieutiques et Océanologiques du Bénin

${ }^{3}$ University of Cape Coast, College of Agriculture and Natural Sciences, School of Physical Sciences, Department of Chemistry, Industrial Chemistry Section, Cape Coast, Ghana.

${ }^{4}$ Centre for Coastal Management - Africa Centre of Excellence in Coastal Resilience (ACECoR), University of Cape Coast, Ghana.

*: Corresponding Author calebemidi@gmail.com

\begin{abstract}
Prionace glauca, blue shark is a cosmopolitan species. Together with Carcharhinus falciformis, it co-dominated the landings of carcharhinidae sharks at the Artisanal Fishing Port of Cotonou. The objective of this study is to determine the demographic parameters of the blue shark in Gulf of Guinea marine waters. The different routines of the FISAT II v 1.2 software associated with the empirical equations of Froese and Nohland, allowed the evaluation of the different demographic parameters of the blue shark in Benin's marine waters. From August to December 2015, 244 individuals shark sizes; ranging from $175 \mathrm{~cm}$ to $325 \mathrm{~cm}$ were sampled. The total asymptotic length obtained was $341.25 \mathrm{~cm}$ with a growth rate of $0.35 /$ year, which indicates that the species is growing rapidly and the optimal total length of the species is $232.01 \mathrm{~cm}$. The age of first maturity of the species is 3 years with a longevity of 10 years. The exploitation rate is $\mathrm{E}=0.74$ with total mortality being 2.4; natural mortality is 0.6 and fishing mortality is 1.8 . The sex ratio remains in favour of males throughout the study period. Monitoring programme were suggested with effective management measures established and executed for sustainability of the blue shark's stock in the Gulf of Guinea.
\end{abstract}

Keywords: Carcharhinidae sharks; Prionace glauca; demographic parameters; exploitation; Gulf of Guinea 


\section{Introduction}

Sharks have often been considered in the popular imagination as bloodthirsty killers and threats to humans because of their ferocious appearance and the imposing size of some of them. The real situation is at the opposite end of this perception, with current levels of human activity in the marine environment that could pose a serious threat to the livelihoods of several shark populations (Baum et al. 2003; Baum and Myers, 2004; Baum et al. 2005; Ward-Paige et al. 2010 as cited by Morin, 2014).

Recognized as important components in many marine ecosystems because they generally occupy high levels in food webs (Cortés, 1999), they regulate the abundance and behaviour of lower taxa through predator-prey interactions (Bascompte et al., 2005; Shepherd and Myers, 2005; Ferretti et al.,2010 cited in Afonso, 2015). Also, they are vulnerable to overexploitation (Stevens et al., 2000; Baum et al., 2003 cited by Afonso, 2015) and habitat degradation, (Seitz and Poulakis, 2006; Jennings et al., 2008) among other things to the strategies characterizing the life history of Kstrategy species such as slow growth, late maturity and low fertility (Musick et al., 2000; Garcia et al., 2008). The depletion of shark stocks can lead to serious environmental damage through the expansion of mesopredators and the appearance of trophic cascades. Due to the importance of sharks in the balance of ecosystems and their high vulnerability to pressures, their conservation status must be carefully considered (Morin, 2014).

The shark fishery on the Gulf of Guinea coast is of specific interest to artisanal marine fishers and targets species belonging mainly to the families Carcharhinidae, Lamnidae, Triakidae and Sphyrnidae. Prionace glauca (Linnaeus, 1775) known as the blue shark, is an oceanic and cosmopolitan shark, present between the surface and 152m depth (Compagno, 1992), it codominated this fishery with Carcharhinus falciformis (Bibron, 1839).

The blue shark has been the subject of several publications in most subdivisions of the Atlantic Ocean. In the Gulf of Guinea, publications and data providing information on the demography and exploitation parameters of the blue shark are almost non-existent despite its commercial importance. 
Therefore, the objective of this study is to determine the demographic and exploitation parameters of the blue shark in the Gulf of Guinea (Togo-Benin-Nigeria) that would provide information on the life history of this nearly threatened shark according to the IUCN and fill the gap on Fishbase.

\section{Materials and methods}

Sampling took place at the artisanal fishing port of Cotonou $\left(6^{\circ} 21 \mathrm{~N} ; 2^{\circ} 25 \mathrm{E}\right)$, the main landing camp for Beninese units targeting sharks in Togolese, Beninese and Nigerian waters (Figure 1). The samples were carried out during September, October, November and December of 2015. It is conducted every landing day, i.e. twice a week, considering the traditional biological resting day. All blue shark individuals caught by all shark targeting units are included in the sample. The landings of four units using longlines associated with $5 \mathrm{~cm}$ mesh tuna nets and fishing in the waters of Togo, Benin and Nigeria were monitored. The fishing units are composed of 5 persons and have three-day tides. Each unit carries out two trips per week, considering the day of rest, which could be described as the "Zogbodo" biological resting day.

Landing data were collected monthly and the available information on the fishing units was collected.

Each individual was identified and measured by applying the snout tape measurement to the curved upper lobe of the tail (TL). Maturity in males was assessed by the length of the claspers; in females, maturity was assessed by observing the colouring of the ovaries on evisceration according to Holden and Raitt, (1974). And when possible, weight is also taken. 


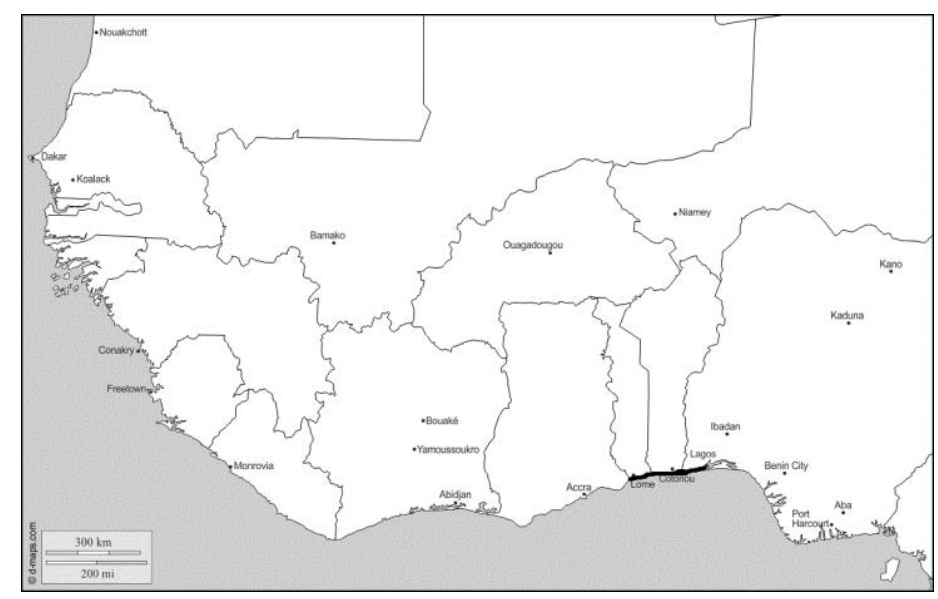

Figure 1: A map showing the West African coast of the Atlantic Ocean with emphasis on the study area.

The normality of the distribution was verified with the Shapiro-Wilk test. When the normality of the data was not met, nonparametric Wilcoxon tests for 2 samples and Friedman rank-sum tests for several samples under R were performed.

\subsection{Sex ratio}

According to Kartas and Quignard, (1984), the sex ratio is the relative proportion of individuals of both sexes in the population at a given time. It is evaluated by the following formula:

$S R=\frac{F}{m} * 100$

where $\mathrm{M}=$ number of males; $\mathrm{F}=$ number of females; $\mathrm{SR}=\mathrm{Sex}-$ Ratio. The sex ratio between the sexes was tested using the chi-square test with a threshold $\alpha=0.05$ under R.

\subsection{Demographic parameters}

\subsubsection{Initial asymptotic length and growth coefficient}

The ELEFAN (Electronic LEnght Frequency I) routine of the FISATII program (FAO-ICLARM Stock Assessment Tools) was used to determine the value of the initial asymptotic length (L $\infty)$ and the growth coefficient $\mathrm{K}$ of Prionace glauca. 
The theoretical age $\left(\mathrm{T}_{0}\right)$ was evaluated according to the following relationship:

$\log _{10}\left(-\mathrm{T}_{0}\right)=-0,3922-0,2752 \log _{10} * \operatorname{L}-1,038 \log _{10} \mathrm{k}$

where $T_{0}$ is the length at the birth of the blue shark, $L \infty$ represents continuous growth of blue shark and $\mathrm{k}$ is the index of growth.

\subsubsection{Total length}

The determined size frequencies allowed the individual growth of Prionace glauca to be estimated according to the mathematical model of individual growth developed by Von Bertalanffy (1934) which considers body length as a function of age through the following equation:

$$
\mathrm{L}_{\mathrm{t}}=\mathrm{L}_{\infty}\left(1-\mathrm{e}^{\mathrm{k}\left(\mathrm{t}-\mathrm{t}_{0}\right)}\right)
$$

where $L_{t}$ represents the length at the determined age of the blue shark, $K$ is the parameter of the VBGF, of dimension year-1 ${ }^{-1}$ expressing the rate at which the asymptotic length is approached; to is the age at length zero if they had always grown as described by the VBGF

\subsubsection{Longevity}

The longevity $\left(t_{\max }\right)$ indicating the age at which $95 \%$ of the asymptotic height L $\infty$ is reached has bee0n estimated using the equation 4 (Cailliet et al.,1992):

$t_{\max }=\frac{5 \ln (2)}{\mathrm{K}}$

$\mathrm{t}_{\max }$ is the maximum age or life span reached in a population (years)

The empirical equations of Froese and Binohlan (2000) evaluated the following parameters:

\subsubsection{Optimal length (Lopt)}

This is the size class with the highest biomass in a population where the number of survivors multiplied by their average weight increases at maximum. It is estimated by equation 5:

$$
\log L_{o p t}=1.0421 * \log (\mathrm{L} \infty)-0.2742
$$

where $\mathrm{L}_{\mathrm{opt}}$ is the optimal length of the blue shark at $\mathrm{t}_{\mathrm{opt}}(\mathrm{cm})$ 


\subsubsection{Age at First Maturity (Tm)}

This is the age at which individuals in a given fish population become mature for the first time. It is determined from equation 6 :

$$
\log (\operatorname{tmax})=0.5496+0.957 \log (\mathrm{tm})
$$

where tm is mean age at first maturity (years)

\subsection{Exploitation parameters}

\subsubsection{Total mortality $(\mathrm{Z})$}

The "Jones and Van Zalinge plot" routine of the FISATII software was used to estimate Total mortality (Z). The empirical equation of Froese and Binohland, (2000) was used to determine natural mortality (M) (equation 7):

$$
\mathrm{M}=10^{\left(0,566-0,718 \log _{10} 1 \infty\right)}+0,02 \mathrm{~T}
$$

where Mis the natural mortality and $\mathrm{T}$ the temperature of considered water.

\subsubsection{Exploitation rate $(\mathrm{E})$}

The exploitation rate (E) was estimated by applying equation 8 :

$$
E=\frac{F}{Z}
$$

where $\mathrm{E}$ signifies exploitation rate of the stock, $\mathrm{F}$ is the mortality fishing and $\mathrm{Z}$ is also the total mortality. The FISAT II "recruitment patterns" routine was used to reconstruct blue shark recruitment rates from size frequency data obtained.

\section{Results}

244 individuals of blue shark were measured using the Total length. Figures 1 and 2 depict respectively the size classes distribution and the mean of individuals by maturity stage. A summary of the descriptive statistical data of blue shark individuals sampled are listed in Table 1. 
Table 1: Statistics of samples.

\begin{tabular}{llllll}
\hline Sex & Number & Minimum size & Average size & Maximum size & $\begin{array}{l}\text { Standard } \\
\text { deviation }\end{array}$ \\
\hline Female & 93 & 196 & 224.6 & 279 & \pm 16.03 \\
Male & 151 & 175 & 255.8 & 326 & \pm 32.27 \\
\hline
\end{tabular}

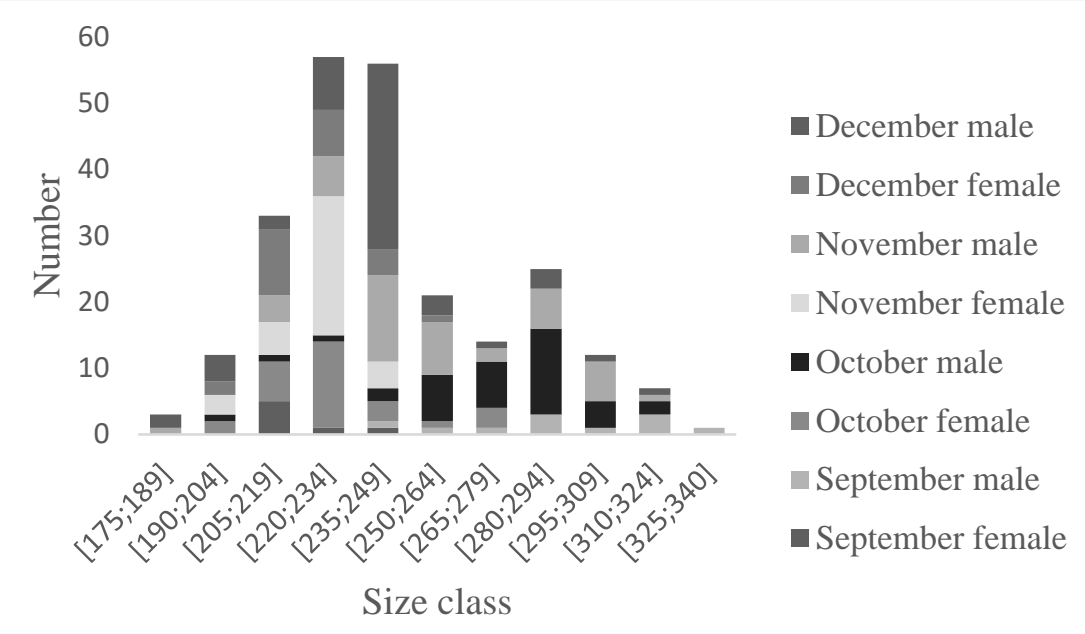

Figure 1: Size class distribution (female-male).

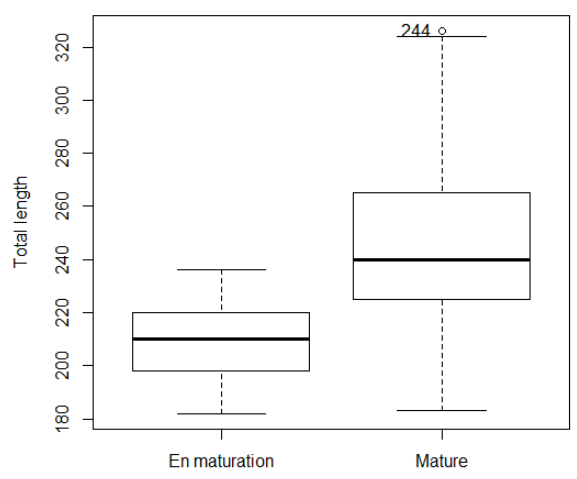

Figure 2: Size function of sexual maturity. 
There is a significant difference between the sizes of males and females ( $\mathrm{p}<0.05$ ). Males were 31.2 $\mathrm{cm}$ taller than females. Considering the sexual maturity, tests carried out showed a significant difference between all months of the study in both males and females (Figure 3).

\subsection{Sex ratio}

The sex ratio in the present study in blue sharks is 0.61:1 showing male dominance (Table 2). This sex ratio is significantly different from the expected $1: 1$ sex ratio $(\mathrm{P}<0.05)$.

Table 2: Sex-ratio by month for the blue shark.

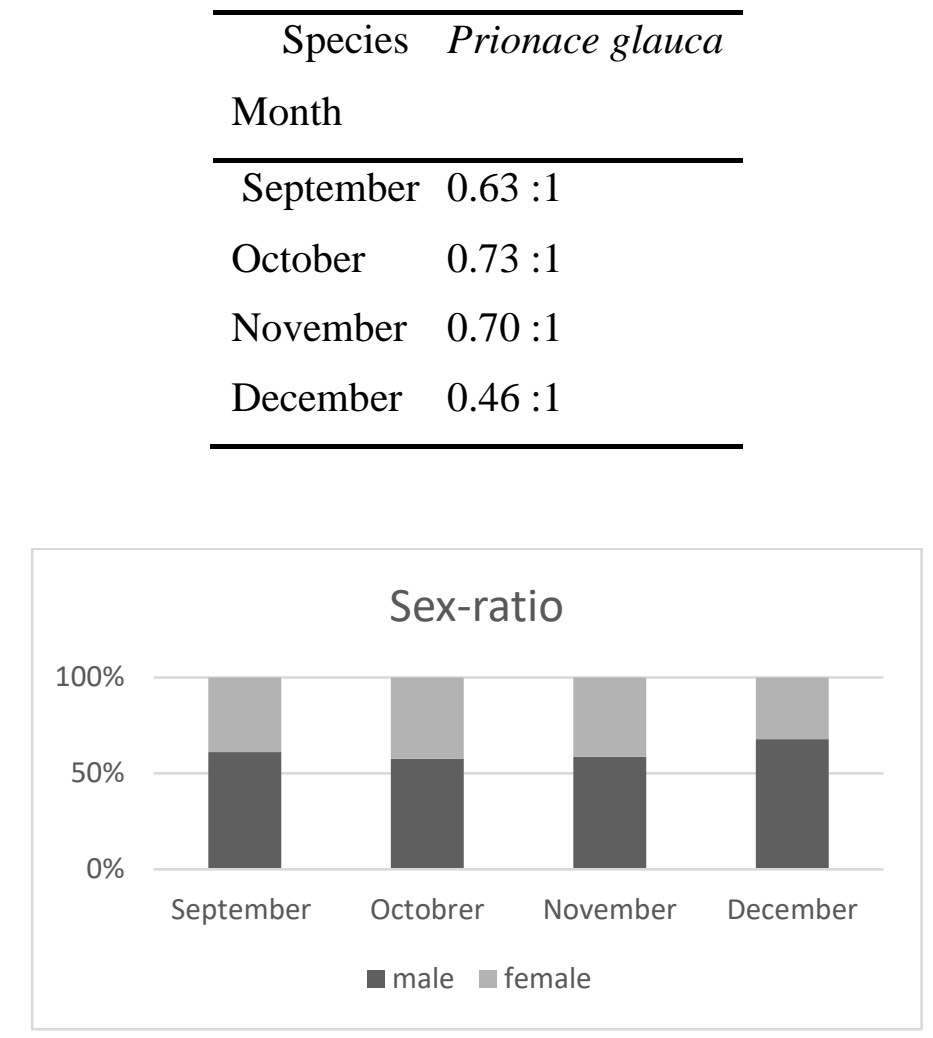

Figure 3: Illustration of the sex-ratio by month.

\subsection{Growth Parameters of the Blue Shark}

A compilation of growth parameters estimated using Powell-Wetherall and Gulland and Holt Plot routines and, Froese and Nohland's empirical equations are presented in table 3. 
Table 3: A summary of growth parameters of blue shark.

\begin{tabular}{lrclllll}
\hline \multicolumn{7}{c}{ Growth parameters of Prionace glauca } \\
\hline Sex & L $\infty(\mathrm{cm})$ & L opt $(\mathrm{cm})$ & K(/year) & $\mathrm{T}_{0}\left(\right.$ year $\left.^{-1}\right)$ & $\mathrm{T}_{\max }$ (years) & Tm(years) & $\Phi^{\prime}$ \\
\hline Female & 278.25 & 222.13 & 0.520 & -0.48 & 13.32 & $3.98(4)$ & 4.445 \\
Male & 341.25 & 232.01 & 0.390 & -0.66 & 8.88 & $2.64(3)$ & 4.657 \\
Combined & 341.25 & 232.01 & 0.350 & -0.62 & 9.90 & $2.95(3)$ & 4.610 \\
\hline
\end{tabular}

\subsubsection{Catch probabilities}

Individuals with a size include in the range from $220 \mathrm{~cm}$ to $235 \mathrm{~cm}$ (maturing and new mature individuals) have a probability of 0.8 of being caught (Figure 4).

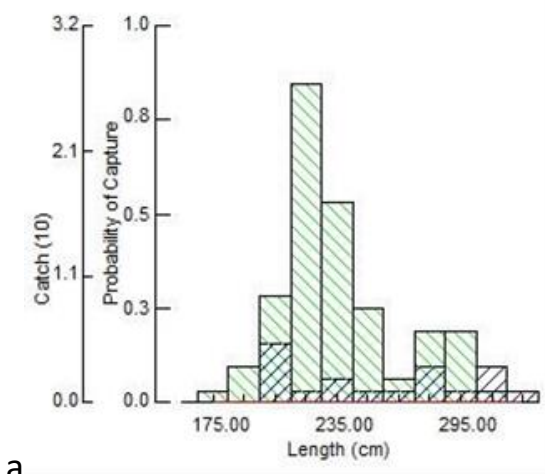

b

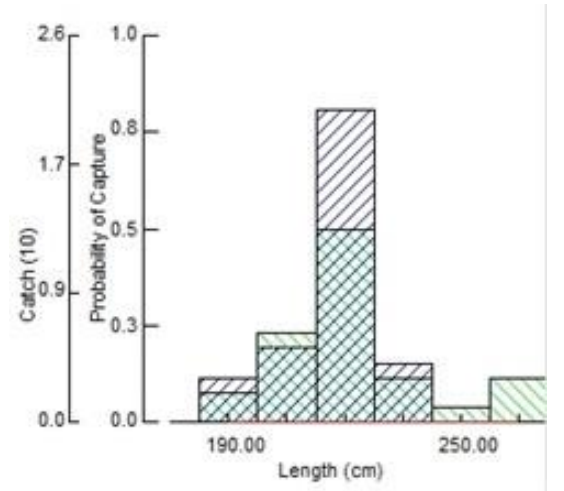

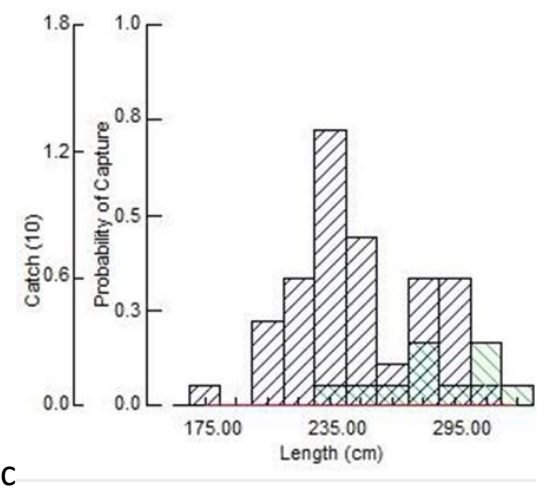

Figure 4: Catch probabilities a- Combined sex; b- Females; c- males. 


\subsection{Exploitation parameters}

\subsubsection{Recruitment}

Significant recruitment is observed at month 5 to replace the dead in the stock and replace 19.95 percent of losses as shown in Figure 4(d).

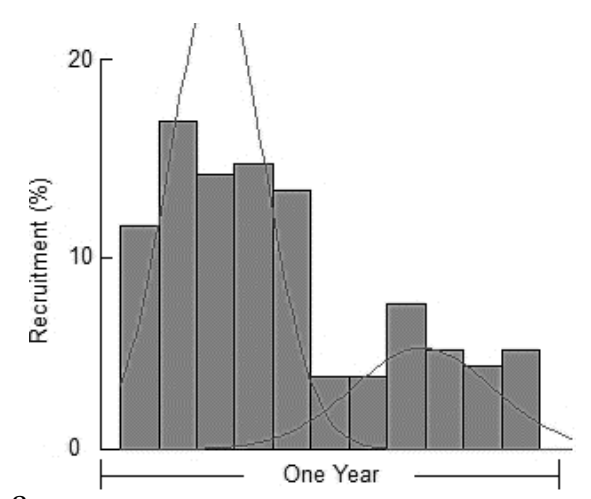

a

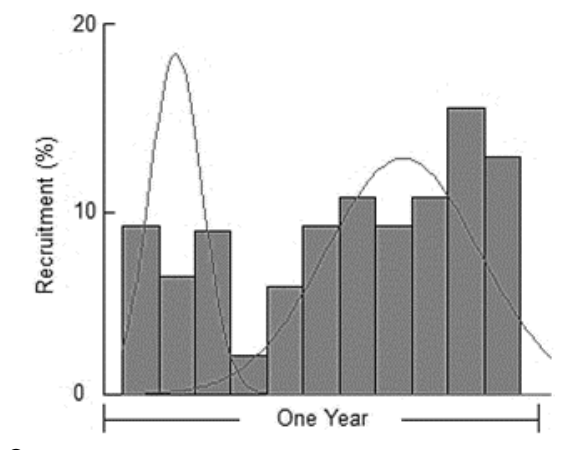

C

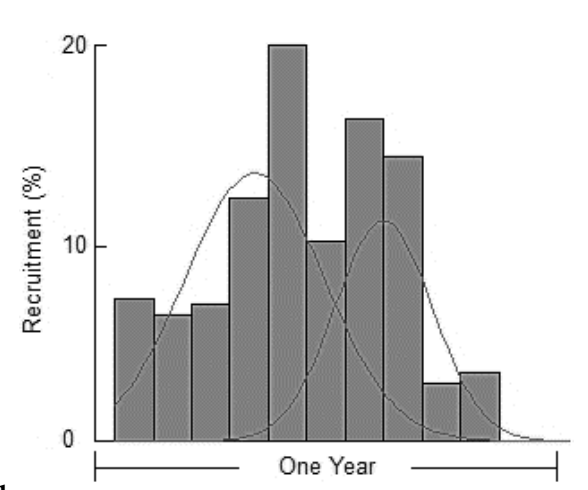

b
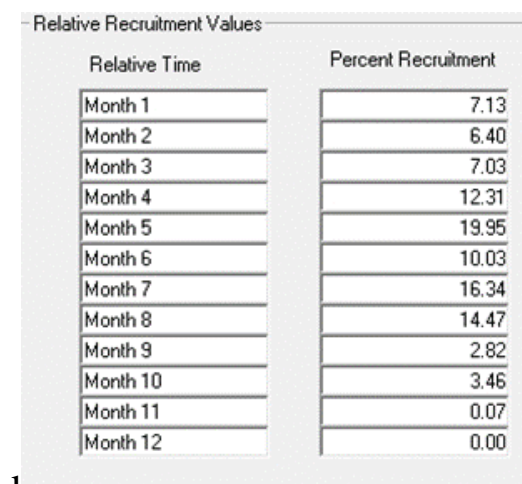

d

Figure 5: Recruitment rate for a: combined sexes; b: female; c: male; d: recruitment values

\subsubsection{Total mortality}

The total mortality obtained from "Jones and van Zelinge" plot using the length size classes 2 and 5 has allowed getting a value of $\mathrm{Z}$ equal to 2.456 with the $95 \%$ Confidence Interval (CI) ranging from 2.225 to 2.688 (Figure 6c). 

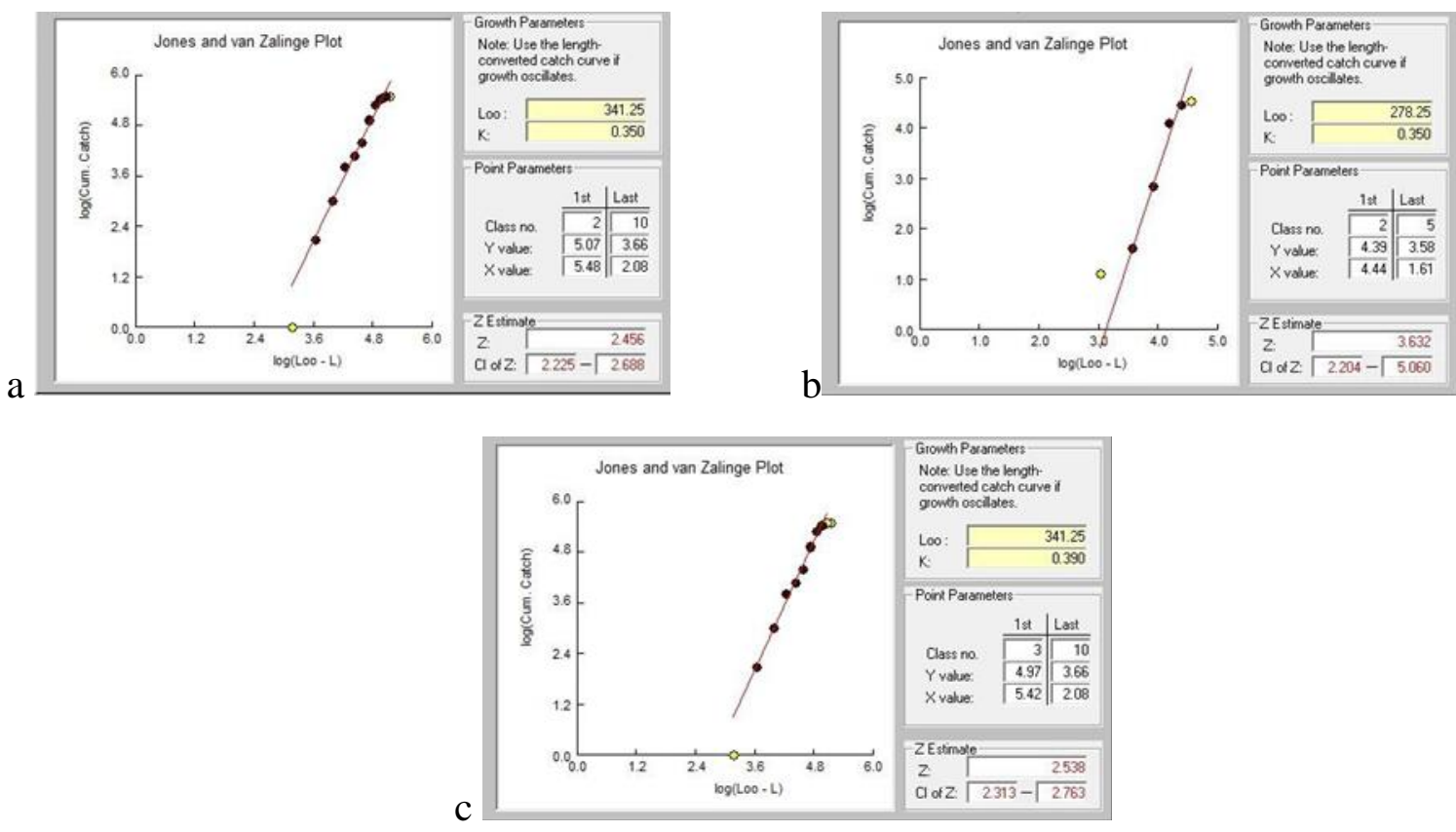

Figure 6: Estimated total mortality for a: combined sex; b: female; c: male.

\subsubsection{Exploitation Parameters}

Relative yield per recruit and relative biomass versus exploitation rate was evaluated to derive the curves of stock dynamics (Figure $7 \mathrm{~b}$ ). The ratios $\mathrm{M} / \mathrm{K}$ and $\mathrm{Lc}$ and $\mathrm{L}$ give values of 1.810 and 0.714 respectively. The values of relative yield (Y/R) (Figure 7a) and biomass (B/R) (Figure7b) per recruit are 0.038 and 0.863 respectively for an exploitation level $\mathrm{E}=0.74$ relative to a fishing effort of 2.456 (Figure 7). The exploitation parameters are presented in table 4.

Table 4: Exploitation parameters of Prionace glauca.

\begin{tabular}{lcccc}
\hline \multicolumn{5}{c}{ Exploitation parameters of Prionace glauca } \\
\hline Sex & $\mathrm{M}$ & $\mathrm{F}$ & $\mathrm{Z}$ & $\mathrm{E}$ \\
\hline Female & 0.644 & 2.988 & 3.632 & 0.82 \\
Male & 0.635 & 1.903 & 2.538 & 0.74 \\
Combined & 0.635 & 1.821 & 2.456 & 0.74 \\
\hline
\end{tabular}



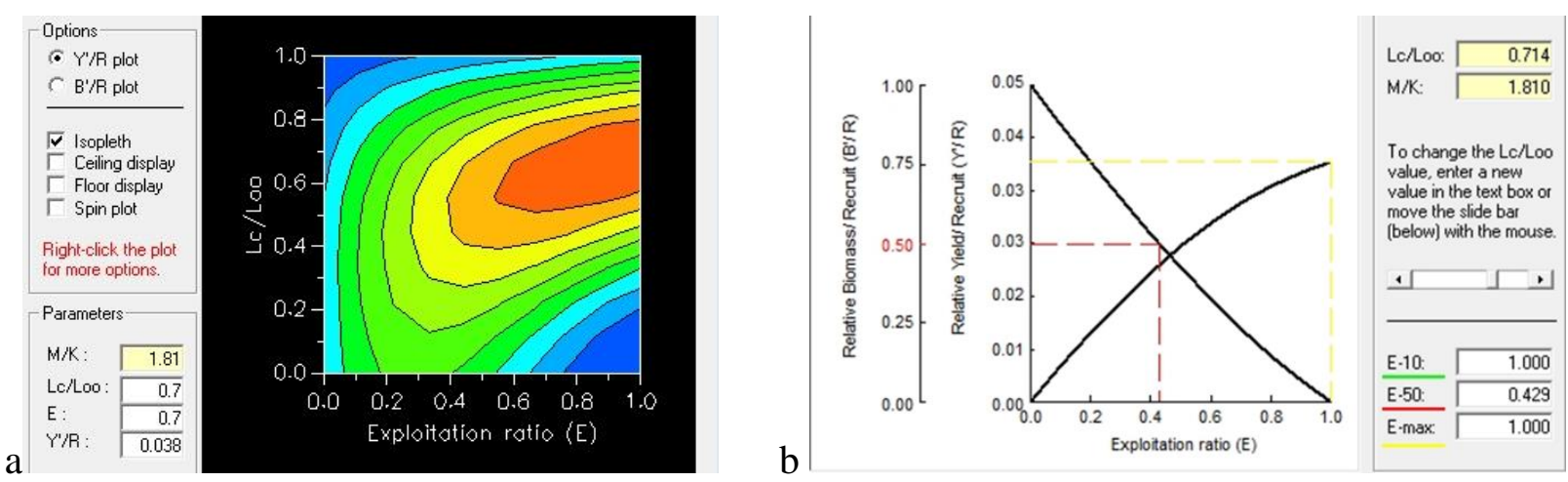

Figure 7 : Exploitation ratio of Prionace glauca : a- Relative Yield (Y/R); b- Relative Biomass $(\mathrm{B} / \mathrm{R})$

\section{Discussion}

\subsection{Sex-ratio}

Like the majority of sharks, this species segregates its population by size and sex several times throughout its life cycle. In the Gulf of Guinea, the sex ratio shows the dominance of males over females. Kholer et al. (2002) obtained a male: female sex ratio of 1:0.8 and 1:0.9 in the northwestern Atlantic, in the northern and southern parts, respectively. Whereas in the north-east Atlantic, the ratio was 1:2.1 and 1:0.3 for the northern and southern parts. Valeiras and de la Serna (2003) obtained a sex ratio of 1:1 in the western Mediterranean. Domingo et al, (2008) in contrast to previous authors showed that in the southwest Atlantic, the proportion of male to female was higher most of the year (2.2:1), except in winter when the proportion was 0.59:1. Megalofonou (2005) at the Mediterranean scale found a value of 1:1.8 significantly different from the 1:1 value. The above sex ratio values confirm the variation obtained for blue sharks for instance. Long-term monitoring will allow us to refine the sex ratio of blue sharks in our area of study. Our results are confirmed by those of Coelho et al, (2014) which showed a sex ratio in favour of males in tropical waters off central-west Africa corresponding to the Gulf of Guinea. Indeed, during their work, among the individuals sampled, 154.523 (46.2\%) were females and 179.784 (53.8\%) were males. It also recognizes the variability in the sex ratios recorded off Brazil and in the waters of the Gulf of Guinea. 


\subsection{Growth parameters}

The age and growth of the blue shark have been studied in the North Pacific, North and South Atlantic. The results of these studies indicate longevity of nearly 20 years, with mature males between 4 and 6 years and females between 5 and 7 years (Nakano and Stevens, 2008). Skomal and Natanson (2003) used sections of vertebrae to estimate age and concluded that the species had longevity between 16 and 21 years and that full maturity was reached around 5 years for both sexes. The longevity and age of the first maturity of the species studied in our area of study give respectively 9.90 (10 years) and 3 years for the maturity of males and 4 years for that of females in the whole population. It is clear that the results are a function of the method used and this calls for verification by a method appropriate for sharks that are long-lived species and reach large sizes and, the features of their habitat (temperate or tropical). According to Lessa et al, (2004) and, Hazin and Lessa, (2005) off Brazil using vertebral length by age classes, the age of maturity varies between 3 and 12 years for males and between 4 and 9 years for females, with modal classes in age groups of 5 and 7 years respectively, which is close to our results. The values obtained for instance for the Prionace glauca's growth parameters are higher than those obtained in the North Atlantic by Skomal and Natanson, (2003) for both sexes separately and for both sexes combined estimated by vertebrae reading and marking. Hazin and Lessa (2005) obtained an asymptotic length value greater than that estimated for blue sharks in our study using vertebrae reading. Values for others von Bertalanffy growth parameters are higher than those in the South Atlantic. Blanco-Parra et al (2008) off the northwest coast of Mexico found values for males and females lower than those found in the Gulf of Guinea. These differences in values are due to the method used.

\subsection{Blue shark exploitation parameters}

The estimated values for the different mortalities and the exploitation rate depict overexploitation of Prionace glauca $(\mathrm{M}=0.635 ; \mathrm{F}=1.821 ; \mathrm{Z}=2.456 ; \mathrm{E}=0.74)$ by the artisanal fishery. Since, the estimate was made with the landings from this fishery, it is worth asking whether it is not high assigning the known number of specialized shark fishing units. What about illegal catches, sport fishing and catches by non-specialised units? It seems, therefore, that this overexploitation is an underestimated of the exploitation rate which should consider the catches of the other types of fisheries aforementioned. Therefore, this estimation is influenced by the year classes taken into 
account in the estimate regardless of the method used. Indeed, Bishop et al (2006) estimated that the probability of catching the largest specimens in the population is low. Not all fish are subject to the same fishing mortality rate. Large specimens representing a small proportion of the population, and because of their size, are probably the most difficult to catch, which confirms the catch probability of the size classes we assessed and shows that it is maturing individuals that are strongly selected by the fishing gear used.

The values obtained for natural mortality in the Gulf of Guinea are higher than those obtained in New Zealand waters (Fishbase, 2013) for Prionace glauca. This could be explained by the temperature and the method used to evaluate these values.

According to Fordham (2007) due to the low resilience of the shark population, most stocks are unable to withstand modest levels of fishing without being depleted. This latter lead to the low biomass observed that is less than expected. When they were expected to compensate for the losses caused by various mortalities (natural and fishing). Two recruitments are observed for the blue shark. The first group, which constitutes the maximum recruitment, replaces only $19.65 \%$ and the second no less important recruitment replaces only $16.34 \%$ of the individuals lost by the population. Fishers must reduce the exploitation rate to balance the biomass. The exploitation rate obtained is higher than E50 as recommended by Pauly (1983) for rational exploitation of the resource.

\section{Conclusion}

This work is to determine the demographic parameters of the blue shark in Gulf of Guinea marine waters. The obtained results of this study show overexploitation as a consequence of non-selective fishing of all sizes of blue shark. It is recommended for management policies to widen the mesh size of shark nets and to review the number of hooks on longlines. Also, the results of this research provide new information about the life history of Prionace glauca in the Gulf of Guinea, and that valuable information not being available in FishBase. Therefore, this study will enhance the data on Fishbase to improve the available information to the scientific community. 


\section{Acknowledgements}

The authors want to acknowledge Dr Kossi Maxoe Sedzro, for his help to handle the data with the software FISAT. They are also grateful to the fisherfolk who allow the use of their capture for the study. This work was supported by the Government of Benin Republic through his "programme d'appui aux doctorants".

\section{References}

Afonso, A.S., Hazin, F.H., 2015. Vertical movement patterns and ontogenetic niche expansion in the tiger shark, Galeocerdo cuvier. PloS one 10, e0116720. https://doi.org/10.1371/journal.pone.0116720

Baum, J.K., Myers, R.A., 2004. Shifting baselines and the decline of pelagic sharks in the Gulf of Mexico: Pelagic shark declines. Ecology Letters 7, 135145. https://doi.org/10.1111/j.1461-0248.2003.00564.X

Baum, J.K., Myers, R.A., Kehler, D.G., Worm, B., Harley, S.J., Doherty, P.A., 2003. Collapse and conservation of shark populations in the Northwest Atlantic. Science 299, 389-392. DOI: $\underline{10.1126 / \text { science. } 1079777}$

Bishop, S.D.H., M.P. Francis, C. Duffy and Montgomery J.C., 2006. Age, growth, maturity, longevity and natural mortality of the shortfin mako shark (Isurus oxyrinchus) in New Zealand waters. Marine and Freshwater Research 57: 143-154. https://doi.org/10.1071/MF05077

Blanco-Parra, M. P., Galván-Magaña F., and Márquez-Farías F., 2008. Age and growth of the Blue Shark, Prionace glauca Linnaeus, 1758, in the northwest coast off Mexico. Reviews in Marine Biology and Oceanography 43:513-520. http://dx.doi.org/10.4067/S071819572008000300010.

Cailliet G.M., Mollet H. F., Pittenger G. G., Bedford D., Natanson L. J., 1992. Growth and demography of the Pacific angel shark (Squatina California), based upon tag return of California. Aust. J. Mar. Fresh. Res., 43: 1313-1330. https://doi.org/10.1071/MF9921313

Coelho, R., Nikolic, N., Evano, H., Santos, M. N., \& Bourjea, J., 2014. Reunion island pelagic longline fishery characterization and standardization of albacore catch rates. IOTC Working

Document,

IOTC-2014-WPTmT05-12. 
https://www.iotc.org/sites/default/files/documents/2014/08/IOTC-2014-WPTmT0512_Rev_1_-_Reunion_Is_LL_fishery.pdf

Compagno, L., J. V., 1984. Sharks of the world: An annotated and illustrated Catalogue of shark species known to date, FAO Species Catalogue. https://doi.org/10.1002/iroh.19860710229

Cortés, E., 1999. Standardized diet compositions and trophic levels of sharks. ICES Journal of Marine Science: Journal du Conseil 56, 707-717. https://doi.org/10.1006/jmsc.1999.0489

Domingo, A., A. Amorim, P. Miller, C. Arfelli, R. Forselledo, M. Ríos, and F. Y. Doño., 2008. Aspectos del ciclo reproductivo y estructura de la población del tiburón azul (Prionace glauca) en el océano Atlántico Sur. [Aspects of the reproductive cycle and population structure of the Blue Shark (Prionace glauca) in the South Atlantic Ocean.] International Commission for the Conservation of Atlantic Tunas, SCRS/2008/144, Madrid.

Fishbase. 2011. Fish growth parameters for Prionace glauca, http://www.fishbase.org.

Fordham SV., 2007. Alerte pour les requins : Révélations sur les menaces que l'Europe fait courir aux populations de requins, The Shark alliance, p. 17.

Froese, R., Binohlan, C., 2000. Empirical relationships to estimate asymptotic length, length at first maturity and length at maximum yield per recruit of fishes, with a simple method to evaluate length-frequency data. Journal of Fish Biology 56: 758773. https://doi.org/10.1111/j.1095-8649.2000.tb00870.x

Garcia VB, Lucifora LO, Myers RA. 2008. The importance of habitat and life history to extinction risk in sharks, skates, rays and chimaeras. Proc $R$ Soc $B$ 275:83-89 https://doi.org/10.1098/rspb.2007.1295

Hazin, F.H.V. and Lessa, R.P. 2005. Synopsis of biological information available on blue shark, Prionace glauca, from the southwestern Atlantic ocean. Col. Vol. Sci. Pap. ICCAT. 58(3):1179-1187.

https://www.iccat.int/Documents/CVSP/CV058_2005/n_3/CV058031179.pdf

Holden, M.J., Raitt D.F.S., 1974. Manuel de sciences halieutiques, Deuxième partie. Méthode de recherche sur les ressources et leur application. Doc. Tech. FAO. Pêches Rev http://www.fao.org/3/f0752f/F0752F00.HTM

Jennings DE, Gruber SH, Franks BR, Kessel ST, Robertson AL. 2008. Effects of large-scale anthropogenic development on juvenile lemon shark (Negaprion brevirostris) populations of Bimini, Bahamas, Environmental Biology of Fishes, 83: 369-377. 


\section{https://doi.org/10.1007/s10641-008-9357-3}

Kartas, F., Quignard, J.P., 1984. La fécondité des poissons téléostéens. Coll. Biol. Milieux marins. Ed. Masson Paris: 121pp.

Kohler, N. E., Turner, P. A., Hoey, J. J., Natanson L. J., Briggs, R., 2002. Tag and recapture data for three pelagic shark species: blue shark (Prionace glauca), shortfin mako (Isurus oxyrinchus), and porbeagle (Lamna nasus) in the North Atlantic Ocean. Collect. Vol. Sci. Pap. ICCAT, 54(4): 1231-1260.

Lessa, R., F. M. Santana, and Hazin. F. H., 2004. Age and growth of the Blue Shark, Prionace glauca (Linnaeus, 1758), off north eastern Brazil. Fisheries Research 66:19-30 https://doi.org/10.1016/S0165-7836(03)00193-0

Megalofolou, P., Damalas, D., De Metrio, D., 2009. Biological characteristics of blue shark, Prionace glauca, in the Mediterranean Sea. Journal of the Marine Biological Association of the United Kingdom, 89 (3): 1233-1242 https://doi.org/10.1017/S0025315409000216

Morin, M., 2014. La conservation des requins du Golfe du Mexique via l'amélioration des connaissances. Université de Sherbrooke. http://hdl.handle.net/11143/8125

Musick, J.A., Burgess, G., Cailliet, G., Camhi, M., Fordham, S., 2000. Management of sharks and their relatives (Elasmobranchii). Fisheries 25, 9-13. https://doi.org/10.1577/15488446(2000)025<0009:MOSATR>2.0.CO;2

Nakano, H. and Stevens J.D., 2008. The biology and ecology of the blue shark, Prionace glauca. In Camhi M.D., Pikitch E.K. and Babcock E.A. (eds) Sharks of the open ocean: biology, fisheries and conservation. Oxford: Blackwell Publishing Ltd, pp. 140-151. https://doi.org/10.1002/9781444302516.ch12

Pauly, D. 1983. Some simple methods for assessment tropical fish stocks. FAO Fisheries Technical Paper 234: 52p. https://doi.org/10.1002/iroh.19840690521

R Core Team 2018. R: A language and environment for statistical computing. R Foundation for Statistical Computing, Vienna, Austria. URL https:/www.R-project.org/.

Seitz, J.C., Poulakis, G.R., 2006. Anthropogenic effects on the smalltooth sawfish (Pristis pectinata) in the United States. Marine Pollution Bulletin 52, 1533-1540. https://doi.org/10.1016/j.marpolbul.2006.07.016

Shepherd, T.D., Myers, R.A., 2005. Direct and indirect fishery effects on small coastal elasmobranchs in the northern Gulf of Mexico: Fishery effects on Gulf of Mexico 
elasmobranchs. Ecology Letters 8, 1095-1104. https://doi.org/10.1111/j.1461$\underline{0248.2005 .00807 . \mathrm{x}}$

Sims, D.W., 2005. Differences in habitat selection and reproductive strategies of male and female sharks. Sexual segregation in vertebrates: Ecology of the two sexes 127147. https://doi.org/10.1017/CBO9780511525629.009

Skomal, G.B., Natanson L.J., 2003. Age and growth of the blue shark (Prionace glauca) in the North Atlantic Ocean. Fish. Bull. 101: 627639. http://fishbull.noaa.gov/1013/13skomal.pdf

Stevens, J. D., Bonfil, R., Dulvy, N. K., \& Walker, P. A., 2000. The effects of fishing on sharks, rays, and chimaeras (chondrichthyans), and the implications for marine ecosystems. ICES Journal of Marine Science, 57(3), 476-494. https://doi.org/10.1006/jmsc.2000.0724

Valeiras, J., de la Serna, J.M., 2003. Contribución al estudio biológico de la tintorera (Prionace glauca) captura da accidental mente en la pesquería de palangre de superficie de pez espada en el mediterráneo occidental. ICCAT. http://hdl.handle.net/1834/790 